\title{
A energia e a experiência esportiva
}

CDD. 20.ed. 142.7

796.5

http://dx.doi.org/10.1590/1807-55092015000400601
Eduardo Fernandes NAZARETH*

*Instituto de Estudos

Sociaise Políticos, Uni-

versidade do Estado do

Rio de Janeiro.

\section{Resumo}

Esse artigo é parte de um esforço de compreensão do que caracteriza a condição de jogador na prática de esportes coletivos com bola como o futebol, o basquetebol, o voleibol, entre outros. A partir de uma perspectiva fenomenológica, buscou-se compreender em especial um aspecto constitutivo fundamental à experiência de jogar - a energia. Como ela é mobilizada, concentrada e continuamente exteriorizada em ações que se ordenam pela forma da atividade esportiva, determinando a vivência de uma experiência prática singular? Essa é nossa questão central, a ser respondida a partir do método da redução fenomenológica, com a qual visamos compreender justamente como a energia desempenha um papel constitutivo fundamental a essa experiência prática, intersubjetiva, total, integrada, fluente e arrebatadora, que envolve o outro, os objetos, o espaço e o tempo.

Palavras-Chave: Fenomenologia; Microssociologia; Jogo; Esporte coletivo; Energia.

\section{Introdução}

Este artigo visa compreender um aspecto constitutivo fundamental à experiência de jogar, a energia, aqui compreendida em seu sentido global de energia vital, física e mental. Busca-se aqui compreender como ela é mobilizada, concentrada e continuamente realizada nos jogos esportivos, em açóes que se ordenam por uma forma de atividade, determinando, em razão de sua atuação constituinte e organizadora, uma experiência prática singular.

Considera-se fundamental entender o papel desempenhado por uma espécie de "circuito de energia"1 (p.253) gerado pela forma prática dos jogos esportivos coletivos, que se mostram capaz de penetrar e envolver profundamente os participantes e seus corpos no ambiente, em uma mesma linha simultânea e sucessiva de eventos arrebatadores que a competição, nesses termos, acaba por gerar, acirrando o que se considera aqui ser, diante desse envolvimento obtido, uma relação íntegra e total entre ser jogador e mundo do jogo.

Como o jogo obtém a adesão dos jogadores e o engajamento de suas energias? Como essas energias, do ponto de vista dos jogadores, estão presentes no jogar?

Devemos ter em mente que essa energia é mobilizada por e voltada a uma experiência, intersubjetiva e total, com as características de uma atividade contínua, fluente e arrebatadora, dotada de um sentido agonístico e de uma forma que a torna capaz de envolver, encerrar numa esfera de experiência, pondo em relação e em movimento interdependente, os objetos, o espaço, o tempo do jogo e o outro de um modo mutuamente desafiador.

A energia é entendida aqui como um elemento subterrâneo que ora mantém-se como força latente, ora manifesta-se sobre os corpos e entre eles, mas que está sempre animando e suscitando esse movimento sendo um fator intersubjetivo fundamental presente implícita ou explicitamente na experiência dos jogos coletivos.

Nossa questão pode ser melhor formulada da seguinte maneira: como a prática esportiva determina certo modo de experimentar a si mesmo excitando continuamente uma vontade, e por consequência uma disposição a uma concentração e orientaçáo dessa energia, num modo total de ser sob a lógica competitiva dos esportes coletivos? Como essa vontade excitada e a correspondente disposiçấo à exteriorização dessa energia transforma o ser ao se encerrar em uma competição esportiva? Como a lógica do jogo gera a mobilização e a força centrípeta sobre as vontades, unindo-as solidariamente entre si, formando uma mesma vontade contra a de outros, erigindo-se em forças coletivas que entáo se voltam frontalmente possibilitando a vivência de uma mesma experiência íntegra e total? Como o ser então se insere nessa zona intersubjetiva assim inaugurada diante desse simultâneo voltar-se a dos então participantes? 
Nossa hipótese inicial é a de que tal atitude - esse voltar-se a uma "We-relation" (p.163-7), como diria $\mathrm{SCHUTZ}^{2}$ (uma relação entre nós) -, própria dos jogos esportivos coletivos, será gerada pela forma lógica do jogo, na medida em que possibilitará sustentar na

\section{Método}

É fundamental à obra de Edmund Hussers ${ }^{3}$ e à perspectiva fenomenológica aqui utilizada considerar a polaridade entre "noesis" e "noema" ${ }^{4}$ (p.300-34) envolvida no processo de constituição da experiência no curso da qual se estabelece a relação entre ser e mundo. Porquanto, se por um lado devemos considerar os objetos típicos visados ("noemas") no interior de um mundo cujo tema identifica seu contexto na consciência; por outro, esse processo de experienciar no modo de ser jogador não pode ser levado a cabo sem se ter em conta o sentido existencial com o qual essa consciência, por atos intencionais unificantes, motivados por uma vontade, se volta a eles ("noesis").

A partir dessa consideração, a fim de compreender como se dá a relação do ser com o mundo na experiência de jogar, adota-se o método da redução fenomenológica, que consiste basicamente, como a descreve MerLEAUPonTY ${ }^{4}$, em distender os fios intencionais que justamente prendem o ser ao mundo, por meio da reflexão, pondo entre parênteses o sentido ontológico naturalizado dos objetos, assim como todos os conceitos ejulgamentos de senso comum a ele referidos ${ }^{5}$, de modo a, metodologicamente, recusar, romper e problematizar a atitude natural com a qual habitualmente nos voltamos e vivenciamos o mundo. A finalidade éa de, num olhar analítico - enfocado na vontade e na energia mobilizada e orientada a ele -, descrever como o corpo próprio, objetos e outros corpos se apresentam à consciência nos jogos coletivos, produzindo, tal encontro, a própria experiência esportiva - entendida aqui como profundamente integrada em função justamente da vontade unificante ${ }^{6}$ (p.217-8) que o jogo, enquanto

\section{Resultados e discussão}

\section{Vontade como parte constitutiva da "inlusio" do jogo}

Basta ver um jogo ou ter jogado para notar que a dinâmica interna de uma partida é capaz de relação uma força centrípeta aderente excitando e galvanizando as vontades dos participantes, dando-lhes vazáo de acordo com uma economia libidinal própria dessa prática coletiva que, como sabemos, se mostra capaz de seguir sustentando um circuito de energias.

forma, é capaz de proporcionar ao ser na duraçáo dessa experiência, incorporada e espacializada nesse mundo ao redor ${ }^{7}$ (p.38) próprio do jogo.

A partir da reduçáo fenomenológica aplicada à compreensão da experiência esportiva, busca-se justamente explicitar ao menos uma dimensão básica dos processos subjacentes constituintes da relaçáo simbiótica do ser jogador com o mundo do jogo. A fim de compreender como tal relação se apresenta, nos utilizamos de observaçôes feitas durante trabalho de campo realizado com uma equipe de basquetebol juvenil de importante clube do Rio de janeiro, de relato sobre um histórico jogo de basquete feito por um grande treinador e até de um vídeo que ilustra o aspecto menos visível do engajamento coletivo de energia nos jogos esportivos coletivos. Trata-se de materiais muito diversos que permitem, cada uma deles, explorar mais detidamente as diversas dimensóes do fenômeno.

Por meio da redução fenomenológica, essa relação se evidenciará em sua profundidade. Veremos como o ser jogador ai no mundo do jogo, conformada por traços pré-pessoais, se torna parte de um ser próprio, autêntico, no curso das experiências reais de uma partida, na qual a pessoa deles se apropria no contato com as forças mundanas vivas de uma partida, que emergem organizadas pela ordem prática do mundo do jogo. $\mathrm{O}$ mundo do jogo presente nos eventos da partida (que nada mais é do que a sua concretizaçáo) se apresenta entáo vivamente a esse ser aí como desafio, obtendo, devido à sua forma lógica, a adesão existencial real e sensível, manifesta na própria relação sobressaltada do jogador com seu corpo, com o outro e com o ambiente esportivo ao redor.

vir pouco a pouco nos enlevando ou de pronto conduzindo-nos para os seus confins; não de modo inebriante e inconsciente, fazendo-nos nos perder de nós mesmos, mas, uma vez que saibamos jogar o jogo, induzindo cada jogador a se centrar em 
um nós enquanto nos centramos em uma situação problemática nossa, coletiva, fundindo-nos a ela por meios cognitivos mas também por meio de uma vontade continuamente excitada e de uma energia então liberada e sintetizada nas ações como substância difusa da partida, parte de sua atmosfera, vivida e sentida no corpo. Em outras palavras, a vontade, enquanto necessidade de exteriorização de energias excitadas, é parte da realidade vivida no jogo; como diria HuizINGA ${ }^{8}$, é parte de sua "inlusio" (p.14).

Frequentemente uma vontade de jogar está presente antes do início do jogo, isto é, antes mesmo de estarmos expostos às forças centrípetas que a sua dinâmica exerce sobre a vontade e as próprias energias. No caso em que já se praticou o esporte em questão, essa vontade inicial remete-nos à vontade de vivenciar algo que já se vivenciou, e que já se conhece em sua tipicidade, bem como a uma necessidade de revivê-la, que por sua vez parece se conectar com a intuição de certo reequilíbrio prazeroso das energias proporcionado pelo jogo. Esse é um espaço em que as energias podem se comprimir para em seguida se descarregar em fluxos impetuosos de ação, investidas profundamente de um sentido atual de afirmação de si sobre o mundo ao redor. Assim, esse mundo e sua realidade efetiva não se presentificam plenamente para nós como algo corriqueiro e desimportante, mas de fato como algo extraordinário que nos arrebata e transforma profundamente.

A vontade de jogar é a própria vontade de ver essa energia se criar e liberar de modo ordenado, numa atividade prática ativa, cujo sentido originário a refere a uma potência do ente exercida no ser jogador. Toda a "in-lusio" do mundo, sua aparência ainda do seu exterior, é então trazida consigo por essa vontade.

A mobilização e o engajamento de nossas energias ao voltarmo-nos a esse mundo é um fator sensível que corre nos subterrâneos do ser, sendo imprescindível à irrupção autêntica da presentificação e, posteriormente, da sustentação da própria "in-lusio" do jogo, pois a vontade ou a necessidade de jogar cria uma força propulsora sobre o ser na direção do mundo do jogo, um impulso originário continuamente atualizado como tal com a própria prática, remetendo-nos à própria forma da atividade, que justamente é capaz de gerar e sustentar um equilíbrio de tensóes, com represamento e extravasamentos regulares de energias, culminando de tempos em tempos em fluxos mais abruptos ${ }^{\mathrm{a}}$.

A vontade de jogar traz consigo um conjunto de disposiçôes próprias de um modo de ser jogador forjado em uma conexão previamente estabelecida com todo o mundo do jogo ao longo da sedimentação de experiências anteriores nas quais se constituíram as próprias competências, disposiçôes e certo hábito de jogar. No ato de decidir jogar essas energias já foram anteriormente ordenadas e estão prestes a serem ativadas, atravessando e unificando os jogadores sob a forma da atividade real e já familiar que então a submete a sua ordem de sempre, colocando-nos em nós mesmos e totalmente dentro desse mundo já conhecido do jogo. É sob essa vontade previamente modelada que se voltam nosso olhar consciente, nossas disposiçóes e energias ao mundo do jogo.

Assim, esse mundo e sua realidade efetiva não se presentificam plenamente para nós como algo corriqueiro e desimportante, mas de fato como algo extraordinário que nos arrebata e transforma profundamente. A vontade precipita ou antecipa todo o mundo do jogo em sua densidade e profundidade, antes dele de fato se apresentar, tornando viva, embora apenas como antecipação, toda a sensação de se estar sob suas forças concretas. Suscitando o impulso constituinte da consciência, fazendo surgir toda sua organização interna, ela já evoca, enformada, a energia do jogar.

A vontade, como se pode notar, não só é um elemento constituinte da realidade do jogo como também, já dentro do jogo, diante dos eventos, lança nosso ser na aproximação desses eventos, isto é, ela nos aproxima do que se aproxima ${ }^{9}$ (p.152-9). Trata-se de uma disposição à aproximação não só no espaço como no tempo, do lance da disputa a seguir, em sua lógica interativa mais ou menos familiar. Diante da disposição dos demais de igualmente se aproximar e se manter próximo de um núcleo de acontecimentos que entáo podem se desdobrar, a força da vontade pode se exteriorizar em açóes mutuamente referidas numa zona intersubjetiva que se conforma entre nós. Nós então nos aproximamos existencialmente de nós mesmos nesse espaço ao redor.

A vontade cria um estado de prontidão, uma expectativa, que nos lança completamente no presente sintetizado ao futuro imediato, isto é, num círculo espaço temporal que apresenta um horizonte praticamente relevante em que nos situamos - que GARFINKEL ${ }^{10}$ chamou de acento constitutivo dos eventos (p.191) nos quais somos inteiramente devido às exigências da disputa; o que também deriva em última instância do domínio da própria forma lógica do jogo - no sentido prático que Wittgenstein dá ao termo em relação à linguagem ${ }^{11}$ - e de seu caráter urgente e decisivo, típico das situaçóes de disputa geradas pelos esportes.

Por seu turno, o modo de ser requerido pela prática nesse mundo a que nossa vontade nos lança parece obter de nós a energia necessária para que nos mantenhamos 
completamente no centro dos acontecimentos, pois todo nosso campo de consciência ${ }^{12}$ (p.12) se tornou disponível a eles com a abertura existencial própria do lançar-se na partida. É o impulso que a vontade cria sobre a prática que a torna capaz de nos fazer aprofundar nela e em sua temporalidade, nos retirando ou nos distanciando do mundo ordinário e cotidiano e de uma posição potencialmente mais retraída para uma atitude que ressalta e impele o ser a nesse mundo desafiador, que o atrai, o puxa de dentro de si. A prática do jogar não é uma atividade que tome apenas uma parte superficial de nosso ser. O "equilíbrio entre dificuldade e habilidade"13 (p.54), que caracteriza qualquer desafio, ainda mais na forma que assumem os desafios esportivos, exige a plenitude do engajamento de nossas competências e de nossas energias, requerendo de nós nossa inteira atenção e assim a manutençáo contínua do lançamento pessoal e coletivo nessa atividade.

A prática do jogo é inteiramente envolvente. Ela não exige de mim apenas esforço físico ou apenas o cumprimento repetitivo e exterior de movimentos. Por outro lado, ela não exige tão somente tomadas racionais de decisão. Ela requer e toma nossa cognição, ou seja, a nossa capacidade de reconhecer que estamos em uma situação determinada que nos envolve e a nosso corpo, em uma sucessáo de movimentos significativos em um campo ordenado de intençôes, vontades, ímpetos, energia, a animarem a totalidade de nosso ser no competir.

Ao ativar uma competência, a vontade sustentada pela forma da prática integra percepção, cognição, raciocínio, emoçóes e o corpo de um modo convergente imediatamente referido a um mundo propício a essa integração, um mundo em que a realização de tarefas estruturadas e sequenciais, sobre o suporte físico adaptado a elas, já se encontra mais ou menos estabelecido, gerando instantes a que o ser como um todo se lança a uma disputa que avoluma as energias gerada pelo passado imediato e as precipita sobre o que possa ocorrer no agora e no devir imediato diante do constante estado de potencialidade prestes a se realizar demandando açôes decisivas.

\section{Energia e forma da atividade}

Venho me referindo à ideia de energia em seu sentido global de energia vital - uma energia que assume um caráter ao mesmo tempo físico e mental. Refiro-me à totalidade das forças da pessoa que são mobilizadas e orientadas ao encontro competitivo, cuja forma prática segue náo apenas mobilizando-a mas também organizando sua distribuição, que se irradia pelo corpo, sobre os objetos, os outros corpos, pelo espaço e no tempo da partida, circunscrevendo-se na zona intersubjetiva de nossa disputa, na qual se exterioriza de acordo com a lógica da prática do jogo.

Essa mobilizaçáo se dá diante do seguinte dado fundamental a que essa lógica, como um todo, deve corresponder: a percepçáo do nível do desafio, que se determina a partir da comparação antecipatória entre as capacidades que se acredita que a própria equipe possui e aquelas que o oponente supostamente tem. É esse dado que gera a mobilização da energia para o encontro. Essa tomada de consciência da atividade é inerente à "abertura do pré enquanto pré de um poder ser"' (p.201) jogador aí no mundo do jogo nessa partida, que "é ela mesma um modo do poder ser da pre-sença (ou do ser aî)" (p.203).

É a partir de um equilíbrio entre o controlável e o incontrolável, sob o fundo mais ou menos ordenado desse mundo, que se sustentam meta e impulso ao arrebatamento na atividade, desse modo propiciado pela forma da prática em sua totalidade. Sem esse componente de equilíbrio tendente ao descontrole, demandando esforço e ação, de onde surge o desafio, a autenticidade do lançar-se inteiramente pode se perder, e a energia engajada pode assumir um caráter, por assim dizer, parcial, burocrático, tornando-se até mesmo uma obrigaçáo continuar. Perdendo-se o sentido de desafio, jogando-se apenas para completar a partida, o ser jogador aproxima-se do seu sentido impróprio, impessoal ${ }^{9}$.

Nos jogos esportivos, o sistema prático deve prover as condiçóes para que a exteriorização das energias se dê de modo a sustentar o envolvimento espontâneo entre os jogadores durante a partida ${ }^{b}$. E para isso ele deve propiciar continuamente ao longo da atividade um sentido de equilíbrio entre controle e descontrole entre as habilidades que se acredite e se demonstre possuir e o nível percebido do desafio total, a ponto de estimular o engajamento de mais energia. E na tentativa de realizar esse controle diga-se de passagem, programado para ser sempre instável e precário (o controle de uns encontrando seu limite no de outros e na resistência da natureza) - os jogadores devem enfrentar e submeter sua ação a uma forma prática. Essa forma prática prevê a tensão de energias orientadas antagonicamente e exercidas de modo ordenado no tempo e no espaço, requerendo, num nível sempre intensificado de atividade, concentração e descarga ora contida ora impetuosa (mas sempre bem coordenada) de energia, mantendo-se entretanto os excessos sob o controle último da regra, cujos limites visam justamente (dentro de parâmetros aceitáveis de agressividade), 
garantir a segurança dos participantes, a continuidade e a fluência excitante da disputa.

O sistema prático deve oferecer, portanto, uma forma de exteriorização das energias em comum, sendo ela dotada de uma dimensão predominantemente espacial, isto é, uma forma interativa para ações simultâneas no tempo imediato; e de uma forma predominantemente temporal, cíclica e progressiva, referente à duração de toda a relação competitiva de uma partida. É da inter-relação dessas duas dimensóes que a realidade comum do jogo se constitui, tornando-se capaz de modelar essa energia no tempo e no espaço comuns em função dos mesmos eventos produzidos sob a mesma ordem de atividade.

Em todo o ambiente efetivamente experimentado sustenta-se a tensão do desafio e da disputa. Desse desafio que nos envolve e unifica emerge o sentido pulsante de vida sobre a existência. As energias permanecem constantemente orientadas a esse ambiente. Desse modo, ambos - forças naturais e humanas - totalizam a força desafiadora sintética dos esportes. Em sua articulação constituem, em termos bergsonianos ${ }^{6}$, a matéria que exerce uma força que pesa sobre os jogadores requerendo deles uma força de vida própria no sentido de erguê-la, controlá-la e superá-la enquanto a mobiliza contra o oponente.

De acordo com a organização do desafio, a exteriorização dessa energia mobilizada adquire também algo de dinâmico, que se refere ao fato de que ela se realiza no ambiente em movimentos com direçóes e intensidades mais ou menos regulares em disputas geradas pela forma social do jogo, pelos canais de ação coletiva por meio dos quais podem fluir, em um ritmo com que se percorre o trajeto de um ponto inicial até seu fim, passando por seus pontos intermediários até uma culminância, ao longo do qual um "quantum" dessa energia é coletivamente mobilizado e distribuído na sequência de açóes.

Um lance em uma partida amadora de futebol americano $^{14}$ que circula nas redes sociais pode nos ajudar a compreender com maior clareza o que acaba de ser dito. A bola está na linha de "screemage". A equipe no ataque iniciará uma decida. Equipes alinhadas. A bola entra em jogo. O "quarterback" a recebe e se comporta como se a jogada tivesse sido paralisada. Todos relaxam. Ele então corre para a "end zone", com uma defesa inerte. O surpreendente nessa jogada - o fato dos defensores não reagirem a tempo demonstra: 1) o quanto nós, espectadores, esperamos que, em uma disputa esportiva, atacantes e defensores exerçam mutuamente força e resistência; e 2) o quanto para os próprios jogadores essa inter-relação é um dado existencial constitutivo da experiência de jogar, sendo tal força e resistência exercidas mutuamente por eles mesmos um dado existencial já naturalizado característico do ser jogador no mundo do jogo.

No vídeo, a expectativa de que o jogo só começa ou reinicia mesmo náo exatamente com o apito do árbitro ou com a ação de quem deve recolocar a bola em jogo, mas diante da força que normalmente se exibe nos corpos de atacantes, a que corresponderá, uma vez percebida, a ação defensiva (às vezes um pouco antes com a ordem invertida). É aí que se ativa a relação de uma resistência simultânea, antagônica e complementar por parte de defensores à ação dos atacantes. É essa expectativa que parece se frustrar quando esse atacante se comporta como se ainda não estivesse valendo, apesar de se ter recolocado a bola em jogo. Mas apesar disso era como se a bola não estivesse em jogo de fato, pois não se teria aplicado a força deflagradora da dinâmica competitiva a que se encontra condicionada a resistência que a defesa deveria opor.

A um gesto corporal que em nada denotava a força no sentido da meta correspondeu uma desmobilização e paralisação defensiva relativa, dissipando-se a tensão já presente na abertura à jogada. Os corpos, então relaxados, deixavam de sustentá-la. Então, nesse momento, o jogador com a bola, que então caminha despreocupado e lentamente avançando sobre o campo, de repente, passa a agir de modo competitivo, correndo velozmente em direçáo à meta como se a disputa estivesse em curso normalmente diante de uma defesa perplexa e atrasada em sua reação. E é isso o que justamente surpreende na imagem, porque não se trata exatamente de ação fora da regra do jogo. A bola estava em jogo, o tempo estava correndo. Não era uma ação violenta. Fica a questão: trata-se de um recurso, da astúcia que um jogo deve comportar ou de jogo desleal, com uso de má fé para contornar a disputa?

Nesse processo, de acordo com a organização do desafio, a exteriorização dessa energia adquire algo de dinâmico, que se refere ao fato de que ela se realiza no ambiente em movimentos com direções e intensidades mais ou menos regulares em disputas geradas pela forma transcendental do jogo, pelos canais de ação coletiva em que podem fluir, em um ritmo com que se percorre o trajeto de um ponto inicial até seu fim, passando por seus pontos intermediários até uma culminância, ao longo do qual um "quantum" dessa energia é coletivamente mobilizado e distribuído na sequência de açóes.

Trata-se de uma atividade competitiva ordenada de modo a que possa de fato sustentar o envolvimento espontâneo de energia no tempo e no espaço 
de uma experiência. O que significa que a forma da competição esportiva deve oferecer os termos em que energias coletivas possam se confrontar como forças que se exercem mutuamente (como força e como resistência), pois é diante do sentido competitivo e desafiador da ocasião que os participantes, identificados a uma ou a outra parte, tentarão, na medida da própria capacidade e do que a regra permite, dar o máximo de si exigindo o máximo do oponente para superar o presente desafio, que então se constitui vivamente. O "quantum" de energia exigido é imediatamente investido em cada lance na busca seja de dar conta da demanda adversária seja de criá-la na esperança de que o oponente não consiga impedi-lo.

Esse "quantum" oscila com um ritmo no curso da interação a que se destina, dentro de sua forma mais ou menos habitual e mais ou menos dentro do que se é capaz de dedicar em um desafio real, vivo, consumindo intensamente as energias disponíveis. Ao longo do tempo da partida se estabelece uma intensidade de esforço ora maior ora menor, de acordo com o que exige o instante. Há uma economia das energias típica do jogo, resultado da natureza das tarefas que estabelece, do modo como são realizadas e de uma noção generalizada de normalidade. A partir desta noção de normalidade, se erige uma economia mais específica, que se constrói no decorrer de cada partida do seu interior entre os participantes. O que ocorre no interior de uma partida não se explica sem considerar fortemente o que vai se construindo ali, mas, sem dúvida, a sua percepção se fundamenta em um investimento habitual de energia em um limiar compartilhado de normalidade presente nas expectativas constitutivas do que se passa.

Nossas açôes, movidas por essa vontade e pelas energias que anunciam existir, contribuem para a formação de um ritmo endógeno, determinado pela maneira como factualmente conduzimos essa nossa disputa, experimentada em relação a um ritmo normal esperado. Esse ritmo endógeno depende da energia mobilizada pela partida de hoje e da sequência de eventos vivida no seu interior, que é geradora de expectativas concretas, constitutivas de cada agora dentro da mesma partida.

A prática produz um progressivo refinamento da sensibilidade, e uma capacidade de mais ou menos controlar, intencional e conscientemente, uma variação adequada do investimento dessas energias em função de uma percepção própria e mais penetrante em relação ao que requer certos momentos de uma partida e qual o "quantum" de energia a ser mobilizado diante do restante da disputa.
O que não significa que não possa haver um arrefecimento desse engajamento, que pode ser momentâneo e até intermitente ainda que passageiro, pois sustentar a concentração também requer energia e ela nem sempre pode ser mantida. A expressão sair do jogo significa perder o seu foco e deixar de ser atraído para o interior desse mundo que se abriu com o início da partida. É quando a ocupação vai perdendo esse enquadramento, fazendo o eixo existencial necessário se perder, perdendo-se também a capacidade de ver com acuidade o problema colocado pela partida e de ser absorvido por ele.

\section{Forma da ação e mobilização de energias no jogo}

A forma competitiva dos jogos em questão deve oferecer as condiçóes para uma experiência prática agonística, bem delimitada, ajustada, tensa e aderente, que requer distribuição das energias individuais como parte de energias coletivas em uma atividade fluente. Já dissemos que uma característica dinâmica importante dessa forma dos jogos esportivos é que, de um modo geral, ela gera atividades interativas que exigem um excedente de esforço em relação às atividades cotidianas ordinárias. Para isso, ela produz certa economia interna sobre a exteriorização de energia em pequenos ciclos internos de exteriorização e nova mobilização ao longo da partida.

A forma do jogo gera disputas que se colocarão no aqui e no agora, ligando-se com o que acabou de acontecer, orientando-se ao que pode desencadear no futuro imediato. Vive-se sempre em um agora a que a urgência da açáo prende os jogadores orientando a ele as energias. Mas há uma forma lógica inteira do jogo que se mantém íntegra articulando, na razão prática dos jogadores, o agora ao fim da partida, encerrando, ordenando e concentrando os eventos na sucessão de um tempo e espaço específicos, sob a ordem de um mundo cujos elementos estão previamente organizados por essa forma.

Essa forma lógica parece primar por engrenar e totalizar na experiência um movimento interior ativo e um movimento exterior coletivo, em razão do fato de que em parte ela faz esse movimento externo fugir ao controle individual, mantendo-o contudo permanentemente ao seu alcance, de maneira a possibilitar um sempre renovado impulso interior a atuar sobre esse movimento global ao redor em fluxos contínuos de ação intensa sob sua lógica. A lógica desse movimento global é cíclica e temporalmente progressiva com pontos iniciais e de 
culminância para as açóes coletivas. Ela ordena cada disputa real que a ela se submete em sua lógica. É a esse ciclo do movimento coletivo - um ciclo de exteriorização das energias - que os movimentos individuais se veem simultaneamente submetidos.

Quando falamos em fluência da atividade referimo-nos a certa fluência e arrebatamento produzidos por essa lógica e experimentados na sucessão dos eventos da partida, que se mostram capazes de gerar e sustentar adesão existencial entre os jogadores. Essa adesão existencial por sua vez é obtida pela dinâmica real da disputa que é estruturada por aquela lógica e requer sua participação urgente e potencialmente decisiva, absorvendo sua atenção e o sentido de seu ser, inteiramente voltado ao que está em jogo, e orientado por uma vontade integradora e unificante.

$\mathrm{Na}$ medida em que a forma do jogo propicia açóes complementares e funcionais de modo a possibilitar a conformação e a continuidade de uma disputa excitante, produzindo adesão sobre e entre as correntes de experiência dos jogadores, as energias dos envolvidos podem ser mobilizadas e vertidas ao encontro, afluindo de modo concentrado e convergente no sentido dado pela ação coletiva em curso. O que ocorre porque as experiências são voltadas aos mesmos objetivos gerais e organizadas por meios que os encerram em uma cadeia de açóes interdependentes, gerando e atualizando a vontade coletiva numa mesma corrente de eventos vividos em comum.

Para manter intensa a adesão, as formas de disputa nos esportes induzem a que os fluxos de exteriorização de energia se organizem em sucessão ou em simultaneidade de modo a que se gere e atualize o engajamento da energia num sentido centrípeto, necessário a que a disputa coletiva se retroalimente no tempo e no espaço. É característica ainda que essa forma transcendental, conforme interiorizada como competência pelos jogadores, permita que eles possam viver o fluir dessa energia da maneira mais livre possível de obstáculos cognitivos que possam obstruí-lo. A correspondência entre a forma e competência prática é fundamental.

As situaçóes então devem se configurar de modo que se possa perceber um quadro inteligível e congruente capaz de possibilitar uma ação individual integrante de uma ação coletiva cuja lógica prática, por me dominar enquanto a domino, passa a organizar a mim mesmo e a distribuição de minhas energias em minha / nossa realização.

Nesse sentido, a função da bola como objeto central e operador lógico de toda a disputa é fundamental. Ela possibilita aos jogadores estabelecerem uma hierarquia de relevância imediatamente referida a ela - uns devem defender e outros, atacar, dessa ou daquela maneira em função de sua trajetória. A fluência de seu movimento permite que as açóes prossigam fluentemente em coordenação, gerando a concentração e convergência na distribuição da energia dos jogadores no seu transcorrer, sempre definindo e redefinindo endogenamente seu sentido, dentro dos limites de uma forma a que a ação se submete.

Para termos ideia do papel fundamental da bola, imaginemos um jogo de futebol com duas ou mais bolas. Cada jogador teria que fazer uma escolha: qual das bolas deveria ser a referência a partir da qual agir, ou por qual das dinâmicas que ambas provavelmente gerariam ele deveria prioritariamente orientar a sua ação? Os eixos definidores dessas dinâmicas se cruzariam, as energias encontrariam dificuldade de se concentrar e orientar inteiramente em um eixo de disputa. Enquanto se seguiria pelo referencial de um núcleo interativo de disputa, de repente apareceria no seu quadro perceptivo outro, reorientando todo o sentido das interaçóes. Dificultaria mesmo a experiência da produção de tensão, acúmulo e extravasamento de energia a um ponto, que se refere à sequência de uma ação na unidade interativa. Enfim, seria difícil focar a experiência, a ação e a vontade, porque seria mais complicado compreender e definir os traços do quadro; seria difícil perceber o que estaria em disputa para orientar e conduzir de modo unificado e ordenado a distribuiçẫo das energias.

A unificação e a clareza (ao menos em relação aos aspectos mais básicos) do objetivo ${ }^{13}$ (p.54) na constituição da tarefa são importantes para a organização da experiência. O movimento de uma só bola e o fato dela poder ser vista por todos nesse contexto competitivo exercem a capacidade de atrair toda energia possível dos participantes, resultando na convergência das açóes e das energias, na conformação de uma situação e na integração coletiva das experiências individuais, fazendo-as confluir às tarefas assim determinadas pelo próprio jogo - tarefas que devem ser conduzidas de modo simultâneo e mutuamente referido, seja no sentido do ataque ou da defesa. Porquanto os desafios que se colocam para cada equipe e para cada jogador fazem com que cada linha de ação individual se insira em um complexo interativo que se organiza em torno da mesma bola. A lógica desse movimento mantém unificadas as açóes individuais do início ao fim da unidade interativa porque elas se integram em uma cadeia, sempre umbilicalmente vivida a partir do aqui e do agora, referido ao que se passa com a bola, na constituição da ação coletiva da própria equipe em face da ação da equipe adversária. 
Embora um conjunto de fatores existentes mesmo fora da situação competitiva seja relevante ${ }^{c}$, a própria dinâmica interativa entre os jogadores em uma partida cria, de dentro da interação, a necessidade do investimento específico de um "quantum" dessa energia, variando contudo dentro de uma margem normal em que o esforço e o desafio às habilidades se fazem presentes. Sem dúvida, a forma em que a competiçáo se desdobrar cria um equilíbrio de força entre atacantes e defensores, entre linhas e contralinhas, forças e resistências. Mas o modo concreto como um jogador engajará mais energia, requerendo do oponente que responda com uma ação adequada, exigindo uma distribuição específica de energia que se determina do interior de nossa disputa, se determina factualmente na partida real em seu tempo vivo. Esse engajamento sempre maior descreve uma espiral arrebatadora que impulsiona a todos de acordo com uma lógica mais ou menos conhecida e compartilhada entre eles.

Há uma força interativa no sentido de que os jogadores convirjam a um nível de energia. Se a energia engajada fica muito aquém ou além do nível do desafio que se coloca, o jogador ou a equipe ficará muito abaixo ou muito acima do nível de energia necessário para superar o adversário; o esforço, a energia mobilizada ao exercício da força e da velocidade de movimento requerido pela dinâmica da interação competitiva, embora possa permanecer dentro da forma regulamentar da ação, pode perder o eixo de sintonia com o desafio. Excedendo-se na exteriorização de energia em força ou velocidade, o jogador pode esbarrar nos limites das regras, como elas costumam ser aplicadas, arriscando a integridade física dos demais jogadores ou a própria ao deparar-se com os obstáculos da situação, sejam eles impostos pelo oponente ou pelos objetos, podendo ainda correr o risco de que a ação perca em eficácia. A própria prática comum, faz com que o jogador acomode as energias em seus esquemas de ação de acordo com modo mais ou menos eficiente como geralmente se joga, gerando a tendência a manter o nível de envolvimento de energia dentro de padróes comumente esperados na comunidade de praticantes.

Nesses esquemas de ação, as energias são alocadas de maneira mais estável mediante esse conhecimento consolidado acerca do que tipicamente requer cada situaçáo. Mas ainda assim, o acirramento de uma disputa em uma partida pode fazer a energia, até certo ponto mobilizada contra o outro nos termos agonísticos do jogo, se elevar em um nível superior da prática ou transbordar essa forma considerada normal em que habitualmente as energias se realizam e adquirir circunstancialmente um sentido de combate convertendo-se em impulso descontrolado de agressão e em violência.

Com relação à fluência das energias na ação coletiva, na medida em que as açóes individuais são interdependentes e se orientam ao mesmo fim e por meios que as integram, cada linha de ação sofre uma pressão das demais, de companheiros ou de adversários, requerendo delas energias orientadas em convergência para a conformação dessa ação coletiva. Assim, no modo como a forma do jogo determina o fundamento para tais relaçóes de interdependência, cada jogador, já conhecedor do jogo, dispóe-se a, no curso de sua ação, se manter aberto a sofrer e a exercer sobre as demais uma pressáo que gera um contágio mútuo pelas correias de transmissáo dadas pela lógica sabidamente compartilhada das formas de ação típicas, tendentes a uma sintonia em termos de mobilizaçáo e orientaçáo funcional das energias individuais em uma cadeia coletiva de ação que se deve realizar.

Trata-se de uma energia que, se acumulando num ponto e se liberando em outro, sob a lógica da ação coletiva, os agentes exteriorizam em suas açóes individuais suscitando as dos demais, contagiando uns aos outros em sequência, enquanto se exibem sobre o campo, visando um mesmo ponto culminante. Atravessando e animando mutuamente suas açóes, os jogadores infundem energia e tensão nessa zona intersubjetiva nossa.

Essa pressão e essa tensão sentidas se dão por se tratar de uma competição, pois nesse contexto se o jogador náo possui essa energia para responder a essa demanda própria de uma disputa, o movimento coletivo sofre com o fato de uma de suas partes, em um de seus pontos, não ser capaz de sustentar adequadamente a continuidade da ação coletiva no limiar de intensidade (e do exercício de força ou de resistência) que o oponente ou os demais companheiros de equipe, nessa dinâmica, requerem.

Toda a conexão de interdependência implicada na execução de nossa ação coletiva, sob uma lógica que damos como certo que vigore entre nós, faz com que se atue num campo de influências recíprocas na qual submergimos ao decidir jogar, na qual uns puxam e são puxados pelos outros intencionalmente para cá e para lá com movimentos corporais interdependentes na interação. A vontade e as energias envidam a lógica de interdependência que então nos mantém presos podendo nos fazer mover mutuamente, constrangendo e sendo constrangidos pela vontade alheia, constitutiva da síntese sensível de vontades coletivas que então emanam da lógica da atividade. 


\section{Energia no tempo imanente da interação esportiva}

Para entender como uma só linha de eventos faz convergir e galvanizar as energias e as vontades numa partida, devemos partir da forma lógica básica que constitui as disputas no tempo e no espaço. Essa forma lógica demarca o que chamo de unidades interativas. É no interior delas que as disputa reais se localizam e se desdobram sobre o trajeto que elas demarcam no curso imanente da experiência. Geralmente as unidades interativas se configuram e sucedem da seguinte maneira: defesa $\mathrm{A} x$ ataque $\mathrm{B} \rightarrow$ perda da bola por $\mathrm{B}$ [transição] $\rightarrow$ ataque A x defesa B. Cada perda de bola redunda na posse da outra equipe. Demarca-se então o fim de uma unidade interativa e o começo de outra, num mesmo fluxo, com o ponto de inflexáo da troca de papéis entre as equipes. Após a perda da bola daquela equipe que a detinha, quem defendia agora ataca e quem atacava agora defende, e assim sucessivamente. Assim, seguindo prospectivamente na disputa, a forma da disputa constitui e demarca o curso imanente da nossa experiência.

Dentro dessa série básica, energias são orientadas em sentidos contrapostos, do lado defensivo, no sentido de manterem-se os espaços fechados na direção da meta, e do outro, o do ataque, no sentido de abri-los. São energias individuais que são impulsionadas a se articularem como uma só força coletiva enquanto se orientam frontalmente contra a oponente. Cada um dos lados está em uma mesma disputa que requer movimentos simultâneos, coordenados e mutuamente referidos, que se desdobram endogenamente em nossa disputa real como num confronto de forças. Dada a forma do jogo, essa mobilização da força coletiva se mantém constante ora no papel ofensivo, como força, ora no sentido defensivo, como resistência, e sempre de modo dinâmico e coordenado.

Pensando nos termos de um padrão esperado, resultado da sedimentação de experiências anteriores e de um sentido compartilhado de normalidade entre os jogadores, o ataque começa suas açóes mais lentamente, acelerando-as progressivamente em relação ao que faz a defesa, na tentativa de avançar sobre o campo de jogo na direção da meta. Os atacantes tentam avançar pouco a pouco e de modo insinuante, exibindo açóes que induzam os movimentos da defesa a abrirem espaço à condução da bola à meta. Essa ação que se inicia mais lenta se deve ao fato dos defensores, em conjunto, priorizarem manter fechados os caminhos mais diretos à meta que devem defender.
No momento inicial da ação ofensiva frequentemente os atacantes não encontram forte resistência defensiva. Mas entre os jogadores em campo sabe-se que quanto mais os atacantes consigam se aproximar com seus corpos de pontos do campo de onde possam avançar sobre a meta, mais os defensores buscarão aproximar o ajuste temporal entre açóes do atacante e suas reaçóes. A partir de então, a tensão unificante entre as energias de força e resistência se acentua e a coordenação das açóes tende a se ajustar, tal a gravidade do instante e a urgência da ação.

A partir desse ponto da unidade interativa, a defesa visa conter mais ostensivamente o avanço ofensivo, modelando o sentido dessas ações na direção menos efetiva, enquanto os atacantes buscam induzir a defesa a alargar aquele ajuste exibindo açóes futuras que náo prosseguirão para avançar sobre os espaços deixados em aberto. Há toda uma dinâmica entre intenções e energias de contenção e interrupção "versus" de continuidade adiante da ação, isto é, de resistência contra a força (e vice-versa). Essa dinâmica implica que então se submetem a uma mesma economia dos impulsos e de exteriorização das energias já mobilizadas para a partida, assentadas em uma forma de disputa esperada que por sua vez se remete a um modo habitual de distribuição a se adaptar às especificidades de uma partida singular.

Voltando o olhar a essa forma que organiza as interaçóes, de certo modo o ataque é privilegiado pela regra no sentido de que ela lhe garanta certa proteçáo para realizar sua açáo a fim de que, ao tomar a iniciativa, demande, na lógica agonística, uma resposta defensiva que requeira a continuidade da interação com uma nova ação ofensiva e outra defensiva, e assim sucessivamente. Sua ação deve desencadear essa sequência mais ou menos fluida sob essa forma. $\mathrm{O}$ ataque adquire certa inclinação para a tomada da iniciativa porque a forma da disputa lhe confere essa função desencadeadora contínua, restando à defesa responder à sua ação de modo a modelá-la, conduzindo-a a um fim mal sucedido, assumindo a iniciativa da interação nesse sentido dentro de suas limitaçóes.

Desse modo, por mais ativa que seja a defesa, geralmente, ela é levada a orientar sua ação defensiva a uma atitude em boa medida reativa em relação à ação do ataque no sentido da contenção e da redução dos espaços, intensificando-se num ponto ou noutro do curso de ação coletiva a fim de incitar o atacante a responder, a cada passo dado, de uma determinada maneira. Individual ou coletivamente, o defensor, com seus movimentos, visa restringir sensivelmente as possibilidades do atacante e seguir 
modelando com o exercício de resistência à ação, à força que $o$ ataque pode exercer.

Mas nada impede que a defesa assuma a iniciativa da interação, invertendo as posiçôes - a forma interativa é flexível nesse sentido - assumindo a posição de agir e demandar reação do atacante, o que requer energia extra e muita coordenação. Quando a defesa busca assumir a iniciativa do jogo, geralmente passa do exercício reativo de resistência ao exercício ativo de força coletiva que entáo se lança sobre o atacante num sentido específico: o de sufocar, em conjunto, as linhas possíveis de progressão da ação ofensiva, fechando caminhos a dribles e a passes, induzindo-o às piores opçóes e finalmente ao erro. O que, como disse, requer a intensificação bem coordenada de ações de contenção em uma intensidade superior de exteriorização de energia, segundo a forma da defesa coletiva típica a se realizar.

Com a reduçáo dos espaços em um ponto do campo, coloca-se o acento constitutivo dos eventos, ou seja, o foco problemático da disputa, sobre a área desse ponto do avanço já que as possibilidades de superação por parte dos atacantes parecem se localizar nesse ponto onde os espaços são reduzidos ou totalmente fechados por uma parte significativa dos defensores. Nesse ponto, os espaços devem ser mantidos fechados em um momento de força que a defesa exerce sobre o ataque. Retiram-se as possibilidades do atacante situar sua ação num curso mais longo de duração e num espaço maior, forçando-o a preocupar-se com o imediato da continuidade do curso de ação, induzindo-o, em alguns casos, a certo desespero e a prosseguir da pior maneira.

Sendo bem feita, a defesa pode provocar o que curiosamente suscita a sensação de abafamento, de asfixia, de sufocamento; pois diante da redução do tempo e espaço de ação do atacante, retira-se-lhe a condição básica de ter uma percepção mais abrangente da situação em face da pressão defensiva nesse ponto sobre os canais de exteriorizaçáo da energia ofensiva diante da consequente urgência de reação sob o risco da perda da bola (daí a metáfora da asfixia, que ocorre quando os canais de troca de ar são obstruídos). Diante da iniciativa defensiva, a ação ofensiva desse modo pode ser sufocada até a morte.

Avançar a marcação em um determinado ponto de sua ação coletiva, estreitando os espaços, fechando as chances de avanço dos atacantes, requer um senso apurado de antecipação e de coordenaçấo, além de muita velocidade, para realizar, em conjunto, movimentos de contenção em constante atualização. Enfim, é necessário dispor de muita energia física, confiança mútua, e firmeza de propósito.

\section{Uma jogada exemplar}

Um lance típico em especial exemplifica de um modo mais específico como a energia a ser empreendida numa ação coletiva no âmbito de uma unidade interativa estabelece uma ordem de interdependência e uma economia de energia a cada jogador na execução das ações de sua equipe, convertendo-se, na disputa real, força ofensiva em resistência e resistência defensiva em força.

Numa equipe de basquetebol que acompanhei durante pesquisa de campo, uma jogada defensiva era frequentemente utilizada. Para compreendê-la, é importante saber que, para criar esse efeito de asfixia em um ponto da jogada, a defesa recorre à dobra de marcaçáo (dois jogadores marcando o jogador com a bola); o que ocorre em circunstâncias específicas, em especial, quando o jogador de posse de bola se localiza próximo aos cantos do campo de jogo.

A dobra ocorre próxima aos cantos da quadra justamente porque aí as possibilidades de passes e deslocamentos sob posse da bola se veem diminuídas pelo ângulo formado pelas linhas limítrofes do campo de jogo que reduzem os espaços de ação a 90 graus. Para reduzi-las ainda mais, bastam dois jogadores, posicionados perpendicularmente, para fecharem quase inteiramente o espaço de avanço e de passe. Mas para que esse fechamento seja efetivo, esses dois defensores devem adotar o gesto corporal com os braços abertos, restringindo essas possibilidades imediatas, obrigando que o jogador com bola recue ainda mais no sentido do canto para ter maior ângulo para passe ou que empreenda a tentativa de um passe longo e arriscado, enquanto os demais seguem fechando as linhas imediatas de passe, dispostos a aproveitar o erro iminente e retomar a posse da bola.

Essa ação pode estar inserida em um plano defensivo mais elaborado, com funçóes mais bem definidas, como no caso da referida equipe, que apresentavam a utilização tática dessa dobra em uma jogada defensiva total comumente praticada no clube pesquisado ${ }^{d}$. Para compreendê-la, é necessário ter em mente alguns limites formais estabelecidos pelas regras do jogo e que os jogadores nesse nível da prática conhecem. Cada jogador sabe - e dá como certo que os outros sabem, e que os outros sabem que ele sabe, enfim, todos dão como certo que todos sabem - que de posse da bola, deve-se atravessar o campo defensivo em no máximo oito segundos e que após parar de driblar não se pode voltar a fazê-lo, tendo que passar a bola no tempo de cinco segundos depois disso. É necessário também saber que uma 
vez atravessada a linha do meio da quadra com a bola, não se pode retornar para o campo defensivo. Se o fizer a equipe perde a posse da bola.

Vamos à jogada. Logo no início da unidade interativa, o armador da equipe no ataque recebe o passe no fundo da quadra após cesta da equipe agora na defesa. Para realizar essa jogada defensiva, o defensor que marca esse armador ainda em seu campo de defesa deve ocupar o espaço do trajeto desse jogador ao seu campo de ataque por onde ele náo quer o armador passe, empurrando-o para o lado oposto. Ele deve definir claramente um lado para fechá-lo com seu corpo oferecendo o lado oposto para o armador avançar. Este, segundo a regra do jogo, tem oito segundos para cruzar a linha do meio da quadra. O que o defensor está fazendo é levar esse atacante na direção de uma armadilha. O que está em curso é a furtiva fabricação dessa situação ${ }^{\mathrm{e}}$.

Enquanto o armador se prepara para cruzar, antes dos oito segundos, a linha do meio da quadra - de onde não poderá retornar -, o marcador se propóe a, logo em seguida, pressioná-lo ainda mais para o canto. Nesse momento, um dos demais defensores, o marcador do ala atacante desse mesmo lado, deve sair em disparada para fechar o avanço, e fazer a dobra, coordenando-se no exercício de uma pressão sobre o atacante impulsionando ainda mais para o canto na busca de ângulo de passe e de tempo para uma ação. Ambos o fazem sempre impedindo a ultrapassagem especialmente para o meio da quadra e progressivamente restringindo ainda mais o espaço. Enquanto isso, os demais jogadores da equipe devem assumir posições que inibam o passe rápido desse armador a fim de que ele se mantenha com a bola e seja encaixotado. $\mathrm{O}$ marcador do armador e o ala com os braços estendidos, aumentando a superfície de alcance potencial de seu corpo, impedem seu avanço tornando o passe, caso venha a ocorrer, hesitante e inseguro.

Esses marcadores, tanto os que estão no centro dos acontecimentos quanto os que estão no fundo, moldam suas linhas de ação uns em relação aos outros e em relação ao que fazem os atacantes, e engajam mais ou menos energia, a mantém ou a relaxam, no sentido de sempre manter o atacante onde ele está, senão fazendo-o retroceder, fechando as linhas possíveis de drible ou de passe com o obstáculo que seu próprio corpo cria para sua progressão - eles tomaram e estão mantendo a iniciativa das açôes e os atacantes estão apenas reagindo. Os que estão no centro dos acontecimentos e os que estão no fundo sustentam-se mutuamente; no caso dos dois primeiros, ambos empurram o armador para trás com seus gestos ao fechar linhas de progressão, constrangendo-o a buscar um ângulo mais seguro para um passe, até se fecharem quase totalmente as suas linhas com a posição dos corpos em ângulo perpendicular, contra as linhas laterais e do meio da quadra. No caso dos demais, do fundo do lance, e de modo total e interdependente, seguem mantendo fechadas as linhas de passe aos demais atacantes que poderiam recebê-lo. A ideia é que não haja saída fácil e o marcador arrisque um passe alto e lento que tente atravessar a quadra e que seja suscetível ao corte e a um contra-ataque rápido.

Enquanto há esse encaixotamento, o ala do lado oposto, conforme combinado, se coloca pronto para interceptar esse passe. Ele recua de sua posição do lado oposto, onde estaria o jogador que deve marcar, para o meio, discretamente, vigiando a linha do trajeto do passe possível, à espera de que tal passe ocorra para explodir em velocidade em sua direção, interceptá-lo e seguir em contra-ataque para um cesta fácil. Os marcadores da dobra devem tentar ao menos tocar nessa bola para desacelerá-la ainda mais a fim de que esse terceiro marcador, cuja percepção e disposição se orientam para essa possibilidade, tenha tempo de interceptá-lo.

É importante considerar que durante toda a movimentação todos os defensores têm suas posiçóes e funçôes relativas mais ou menos bem definidas e estão engajados nessa mesma ação coletiva visando sustentar-se mutuamente no sentido total de fazê-la culminar em um ponto futuro, em uma surpresa ao atacante, agindo intensamente nesse sentido, cada parte atuando com mais ou menos energia em cada momento dessa jogada inteira que demarca toda a realidade. Todos estes envolvidos prosseguem prospectivamente suas experiências em quase simultaneidade no sentido de criar a armadilha em uma interdependência energética e num tom comum sem o qual a ação não funciona. Cada um sente o impulsionar solidário da energia da ação do outro enquanto estas se exibem, assim como igualmente a exerce, amplificando-se reciprocamente no curso total da ação coletiva até a culminância da sua realização.

Quanto mais apertada, mais pressionada e aproximada dos corpos dos atacantes for a defesa em um ponto do avanço, o que resulta do exercício persistente de força contra o ataque, mais se restringem as linhas de condução da bola pelo campo de jogo, e o ataque, que então apenas resiste, se vê diante de poucas possibilidades desfavoráveis e bastante propensas ao erro. Restringir a movimentação do atacante e impor um limite articulado, um funil estreito ao prosseguimento da jogada, para de repente fechar as linhas quase completamente, costumava ser resultado 
dessa superposição temporal intencional bem articulada sob a unidade da realização dessa jogada, cujos limites marcam o mesmo início, meio e ponto culminante. Em alguns momentos da partida, essa defesa, permitia uma sucessão de erros do adversário e não raro um aumento repentino da pontuação.

Mas, se apesar das dificuldades o atacante for bem sucedido superando a pressão sofrida pela força da defesa, conseguindo resistir a ela, fazendo prosseguir o curso de ação ofensiva para além desse ponto mais problemático, mais espaços estarão abertos a uma larga amplitude de linhas de ação logo adiante já que muitos defensores, mais concentrados naquele ponto, poderão deixar espaços desguarnecidos. Dois defensores se ocupavam de um atacante numa área ainda distante da meta, concentrando naquele espaço mais jogadores, gerando potencialmente um desequilíbrio posterior, daí o risco de uma atitude mais agressiva para a defesa.

O longo passe forçado pela defesa pode ser veloz e bem direcionado a ponto de redundar em situação de pontuação. Ele pode também ser lento a ponto de requerer uma cobertura defensiva bem sucedida; ou a ponto da defesa ser capaz de recompor as suas linhas de contenção sem maiores ajustes, recaindo na defesa normal entấo combinada para situaçóes de jogo de meia quadra, cinco contra cinco.

Os atacantes, assim como os próprios defensores, sabem dessa fragilidade. Eles experimentam esse aperto e constrangimento momentâneos sabendo que ao passar por ele, como por um funil, poderão encontrar uma liberdade maior de escolha logo adiante. Esse funil, que normalmente aconteceria nas proximidades da meta, é empurrado a etapas anteriores da interação por uma defesa que, desse modo, tende a acelerar as unidades interativas.

Esse é um processo ora de contenção das energias num ponto da ação coletiva ora de liberaçáo na sua agudização no sentido da meta, processo esse que tem lugar no interior da unidade interativa. No seu transcorrer, a tensão num momento se relaxa para em seguida se concentrar e se elevarem gradualmente em altos níveis num ponto decisivo, de culminância, diante do acirramento da disputa. Segue-se então o início de nova unidade interativa com as tensões mais relaxadas, acirrando-se quando o ataque se aproxima da meta. E assim, de contençóes e relaxamentos sucessivos se faz o jogo do início ao seu final.

\section{A energia das ações individuais}

Pensemos em um jogador de basquete, de futebol, de handebol, rúgbi, futebol americano ou de qualquer outro esporte coletivo no meio de uma partida. Ele está no âmbito de uma ação ofensiva coletiva que em si, como vimos, possui uma economia própria de energias sustentando uma vontade coletiva entre seus integrantes, voltada contra a vontade e as energias física e mental do oponente. Em algum momento das movimentaçôes (já familiares) em curso, há entradas e saídas para açôes individuais de consequências lógicas mais ou menos decisivas, e ele sabe que é preciso estar atento a esses movimentos para captar o instante certo da sua ação. Ele está imerso nesse movimento e se torna sensível para perceber, segundo as expectativas já consolidadas de acordo com as ações típicas, a possibilidade de uma brecha real na defesa. Imediatamente, no curso de uma protensão, em que num flash antecipa que um movimento seu alargaria um descompasso quase irrecuperável entre os defensores, diante da disposição já assumida, se vê impelido a penetrar a defesa, avançar sobre ela rompendo os elos potenciais de cobertura. Trata-se de um momento fugidio a que o jogador deve estar inteiramente atento no curso do movimento que compóe - o exato momento em que uma brecha se abre ou pode ser aberta com a infiltração é passageiro, pois nesse movimento logo os elos defensivos se refazem. Há um instante certo que é percebido a partir das habilidades que se dá quase como certo (ao qual o jogador deve estar aberto e atento) possuir num pressuposto eu posso f $^{\text {. }}$

Pensemos em uma situação em que esse jogador parta vigorosamente em uma penetração na defesa rumo à cesta para uma enterrada, rumo ao gol conduzindo a bola ou para disputar o espaço com defensores para uma cabeçada, ou em uma corrida para o "try" ou para o "touch down" (metas no rúgbi e no futebol americano, respectivamente). Ele o faz com toda a energia necessária (força, velocidade...), pois dá como certo que os defensores agirão com o vigor usual. Essas expectativas se refinam diante de dados factuais. Do ponto de vista cognitivo, o ponto de partida dessa ação, com jogadores já em movimento em relação à meta, define-se um eixo direcional e um encerramento espaço-temporal à ação, entâo desdobrada como expectativa de realização no seu nascer intencional de acordo com a forma vista no movimento em curso. É de acordo com essa forma lógica que, como uma "gestalt" percebida a partir do próprio corpo ${ }^{\mathrm{g}}$, se ordena o que se passa ao redor, que as posiçôes relativas dos jogadores reais em campo se definem, que se especificam de imediato as respostas ao próprio movimento, que as energias ganham um curso mais preciso, que por sua vez segue acirrando a disputa sob a organização das 
formas de ação ativadas num exercício vivo, fluente e mutuamente referido de força contra resistência.

No curso de sua progressão em direção a essa meta, de acordo com essa forma, o jogador, numa percepção sintética de movimento dos adversários e companheiros em relação ao próprio corpo, mais ou menos de acordo com a "gestalt" ativada, segue antecipando como a contenção mais ou menos precisamente ocorrerá, prenunciando em sucessão possibilidades de ultrapassagem que então se apresentam. Orientam-se as energias por meio do corpo através de um mesmo conjunto prático que as ajustam mutuamente a partir do ponto do trajeto das açóes coletivas e de um sistema de equivalências que opera entre os corpos ${ }^{\mathrm{h}}$ segundo os quais cada movimento de uma das partes corresponde a outro do adversário, modulando as energia a serem engajadas por parte do oponente de acordo com a necessidade que a açáo provável ou já em curso pareça exibir, animando-se a interação.

Ambas as partes, impregnadas do que está em jogo, da força e resistência que exercem reciprocamente, prosseguem adiante na disputa: o atacante com a bola tentando desviar-se dos defensores, enquanto estes buscam impedi-lo que os ultrapasse, posicionando-se como obstáculo, como resistência, usando o choque, se necessário nos fluxos de movimento; a que os primeiros respondem com a sustentação da força física na forma permitida pelo jogo, em movimentos laterais bruscos, se utilizando também do choque mas no sentido de se desviar, de contornar. Tudo com o exercício de uma energia num esforço extra, um apoiando e atritando seu ser individual, coletivamente orientado, contra o outro.

Vistos de fora, e em meio a esses entrechoques, a enterrada, uma arrancada na direção ao gol, ao "try" ou à "end zone”, em sua totalidade típica, se caracterizam ou por um momento inicial de sintonia com o ritmo sequencial do movimento interativo total, recaindo então em um característico e quase autorreferido instante de inflexão, uma parada e uma explosão de velocidade, uma sequência mais ou menos ritmada de mudanças mais ou menos bruscas de direção, conectando-se a uma conclusão com a consequente liberação brusca da energia. Tudo numa linha contínua em que todo o complexo interativo se centra.

No curso mesmo dessa progressão o atacante pode mudar o curso da ação. Uma vez que ele se encontra inserido em um movimento fluente e cambiante, diante de certo equilíbrio entre forças e resistências, possuindo esse movimento entradas e saídas na sustentação da ação coletiva, mesmo que nesse momento ele tenha mantido o foco sobre a meta, esse atacante apoia sua ação num eixo dinâmico que se reconfigura continuamente, de modo que é parte de seu saber prático manter alguma abertura a outra possibilidade de sequência da ação coletiva. Assim, dentro do que a forma lógica ativada sugere (e o jogador pode reorientar, dimensionar e redimensionar seu campo perceptivo ao longo da ação), caso a sequência da ação se mostre improvável, o jogador, diante da contenção defensiva e dos movimentos dos demais ao redor, pode buscar antecipar e disputar a nova sequência dos eventos.

Do interior da vivência da ação, podemos entender que o movimento corporal ora exterioriza suavemente, ora acumula, ora descarrega violentamente energia, como parte de um só fluxo de ação, nessa interação que envida uma forma em que factualmente vivenciamos o jogo, forma na qual uma tensão se acirra, na qual as energias são ora contidas ora liberadas abruptamente esvaindo-se num fluxo final no salto rumo à cesta, no chute a gol ou no salto para o "try" ou para a "end zone", concluindo a ação individual e coletiva. Aquela energia até então canalizada, contida e liberada no gesto decisivo para a realizaçáo do lance, se vê então livre no contentamento e na explosão de alegria. É o salto final para o objetivo a que convergiram todas as energias.

É comum ver o jogador gritar, xingar, socar o ar ou encenar a força que o lance evidenciou possuir, mostrando os músculos, dizendo palavras que ressaltam a própria potência. O que geralmente se faz logo após um lance que tenha exigido dele tamanho esforço, especialmente diante de um oponente que tenha imposto tamanha dificuldade. Em outros casos, a alegria se ressalta traduzindo nas danças bem humoradas. Trata-se dos resquícios daquela energia engajada na forma da ação que agora se solta violentamente dentro de si, libertando-se em vibração, fazendo ressoar a prova da própria potência em face do mundo. A sensação da afirmação de si com a liberdade da inconveniente resistência que teimava em se fazer presente contra minha ação e esforço dá o impulso às expressóes que normalmente se sucedem a lances como esse.

Todo esse complexo de obstáculos que constantemente compóem a situação no agora revelam, um preceder a si mesmo, que coloca em questão para o jogador a sua potência, requerendo sua energia. É a constante busca de uma afirmação e superação do limiar conhecido por mim acerca de minhas capacidades, de minha potência conhecida, projetada e vivamente materializada sobre essa situação real no obstáculo que outro, parâmetro mais imediato para essa avaliação, me coloca, que me estimula a assumir o desafio e engajar mais energia nele e contra ele. 
De todo modo, na forma interativa de disputa dos esportes coletivos, é um dado que a dinâmica de força e resistência criada pela relação simultânea de linha e contralinha no curso de uma unidade interativa crie e oriente a vontade e a ação em um sentido frontalmente antagônico ao do oponente, possibilitando esse sensível provar-se no plano individual e ou coletivo diante desse outro, aqui e agora. $\mathrm{O}$ estabelecimento de uma meta precisa a ser alcançada por uma parte e a resistência controlada a ser empreendida pela outra, ambas alternando-se, sob os limites das formas de ação, criam o sentido dos esforços, e uma maneira de empreendê-los sob condiçóes "a priori” de sustentação da própria atividade.

\section{Energia ao longo da partida}

$\mathrm{Na}$ sucessão das unidades interativas, como resultado das sínteses que as expressóes de força e de resistência originariamente produzidas nas renhidas disputas vividas em cada situação, a atmosfera do jogo se impregna dessa impressão difusa de forças coletivas que se exercem, acirram e se medem mutuamente. Essas energias assim orientadas então adquirem uma expressão temporal em que as equipes se sintetizam e ressaltam na experiência como forças coletivas que ora se reduzem ora se engrandecem frente a outra, configurando o fundo contextual a tudo que se passa na partida, modificável justamente pelos eventos que nele se desdobram.

A duração da partida é permeada de pequenas vitórias ou derrotas ocasionais, individuais ou coletivas, sucessivas ou simultâneas, em que a própria força ora superou as resistências do oponente ou foi superada por ela. Essas pequenas satisfações e insatisfações se acumulam e sintetizam tendendo ora a reforçar uma impressão de superioridade ocasional ora de inferioridade de uma equipe em face da outra. A alternância, mesmo como possibilidade, aviva o contraste entre ambas.

Nesse plano temporal mais estendido, se insere, em razão dessa síntese, um horizonte de possibilidades mais ou menos claro, presente em cada agora, de se vencer ou de ser vencido e que se modifica diante de cada evento que possa ser considerado pelos jogadores decisivo ou que possa indicar uma mudança importante na relação entre forças. Daí, diante de cada novo evento relevante, e do horizonte que apresenta aos envolvidos, o sentido vindouro das unidades interativas se determina num caso pela vontade de sair da posição inferior para a posição superior ou noutro de sustentar sua posiçáo adiante e se for o caso convertê-la em vantagem confortável no placar.
Estamos sempre contidos nos limite de uma situação e de seu horizonte, sob a pregnância das forças coletivas em atrito. Assim que saímos do raio de ação imediato de uma disputa, ainda impregnados do sentido competitivo que ela encena e excita, mas já sob o embotamento do efeito de retenção dessas impressóes, pode se inserir a sensação da continuação da mesma situação ou da formação de um novo sentido, de uma nova situação. Dá-se lugar a outros eventos, e suas impressóes imediatas, dependendo da conexão lógica que sugerem, poderão confirmar nesse novo agora o mesmo horizonte ou inserir na experiência a chance de mudança, a se confirmar ou não logo adiante. Assim, um movimento temporal se constitui orientando em relação à síntese dos novos eventos um horizonte e um sentido específico à vontade e ao engajamento das energias em função do eixo existencial então assumido.

Essas impressóes são sempre ou de força ou de resistência se conformando na sucessão dos eventos concretos da disputa. Pontos de inflexão com redefiniçóes da situação seguem se constituindo a partir das açóes e reaçóes, veículos de energia que jogadores exercem em referência mútua, produzindo assim sensaçóes de continuidade e de descontinuidade imanente no âmbito da unidade da duração da experiência de jogar uma partida.

Vale citar um caso exemplar, da perspectiva de um dos participantes, a partida da final do basquetebol masculino no Pan-Americano de Indianápolis, em 1987, entre o Brasil e os EUA, da qual a equipe brasileira surpreendentemente se saiu campeá. $\mathrm{O}$ caso, relatado pelo treinador brasileiro, Ary Vidal, ilustra como um contexto definido como plenamente favorável aos EUA, cujo retrospecto e tradição no esporte lhe atribuíam um favoritismo inquestionável, foi posto em questão no decorrer da partida a partir de um instante chave, quando uma nova cadeia de situaçóes pouco a pouco foi alterando a expectativa inicial e a conformação de todo o desafio para ambas as partes. $\mathrm{O}$ treinador brasileiro, rememorando a conquista em seu livro, nos diz, reconheço que não começamos bem o primeiro tempo: nossos jogadores sentiam muito o fato de estarem jogando numa final contra os Estados Unidos, a despeito de toda a preparação psicológica que havíamos feito com a equipe. Os americanos, ao contrário, iniciaram a partida confiantes, velozes, dispostos a estabelecer uma grande diferença no placar logo de saída (p.120).

Ao fim do primeiro tempo, Antes mesmo da volta ao vestiário, todos nós havíamos feito o balanço de nossos lucros e perdas: 
LUCROS: fim da tensão inicial decorrente de estarmos jogando a final contra os Estados Unidos (...); a despreocupação de toda a equipe americana (...) PERDAS: vantagem americana de 14 pontos; as faltas cometidas por nossos jogadores Oscar, Marcel e Gerson; nosso fraco índice de conversão, especialmente da linha de três pontos ${ }^{15}$ (p.122).

Logo no início do segundo tempo a situação pouco se alterou (...) Seguem-se dois lances importantes: Oscar faz dois pontos com um belíssimo gancho e David Robinson [jogador então mais promissor daquela equipe universitária dos EUA, e que mais tarde brilharia na NBA, a liga profissional norte-americana] comete a sua quarta falta (...) falta técnica. Oscar cobra a técnica e o placar registra 77x65 [a vantagem norte-americana cai para 12 pontos]. Estamos melhorando e mesmo porque dali a instantes ocorrem dois outros lances. Marcel, muito bem marcado, sai fora da quadra e cai sobre a mesa de cronometragem, o que levanta o moral de nossa equipe. O homem disse que ia se arrebentar e está se arrebentando mesmo... [uma demonstraçáo de força e determinação] Logo em seguida Oscar faz um belo chute da linha dos três pontos. Placar 67x77 (sic). Dez pontos de diferença. [Vidal erra a contagem em algum momento, com esse chute de 3 pontos, o placar ficaria 68x77]. Epa! a coisa tá virando! A situação periga, só que desta vez para o lado dos Estados Unidos. Preocupada, a torcida sente a nossa reaçáo e incentiva a sua equipe [há um sentido intersubjetivo aos eventos entre os circunstantes]. A partida agora começa a pegar fogo! Israel, no rebote ofensivo, apanha a bola, atira, erra, a bola volta de novo para as suas mãos, (...) e Israel converte a bola mais 'chorada' do jogo [nova demonstração de força e determinação]. Placar 69x77 [a vantagem cai para 8 pontos]. E continuamos avançando. A situaçáo está agora mesmo preta para os Estados Unidos, que falham em três ataques consecutivos. Oscar converte um tiro de três pontos e Marcel outro de dois. Placar: 74x77. Olho no relógio: 13,27 para o fim do jogo. Oscar gira e esmurra o ar pela primeira vez. É bom, excelente sinal. Marcel também grita incentiva ${ }^{15}$ (p.125).

Salto alguns minutos do jogo e vou direto ao lance que considero decisivo: Marcel rompe embaixo da tabela adversária, aproveitando a brecha aberta momentaneamente pela 'switch' [uma jogada], atira a bola e recebe falta de David Robinson. Placar: 96x100. BRASIL CHEGA AOS 100 PONTOS E DAVID ROBINSON SAI COM 5 FALTAS. Sem dúvida esse foi o grande momento do jogo. Os Estados Unidos náo mais passariam à nossa frente no placar (....) O placar final do jogo passa para a história do basquetebol. Permita-me, leitor, que ao registrá-lo aqui coloque o nome do Brasil em primeiro lugar. Placar: Brasil, 120x Estados Unidos, $115^{15}$ (p.127).

Em função do sentido intersubjetivo do impacto imediato de cada evento - o ressoar de suas impressóes - cria-se pouco a pouco, com o seu acúmulo, um sentido àqueles lances. Somando-se àqueles anteriores, determina-se o caminho da interação até ali, indicando uma tendência futura imediata, que aviva um horizonte e as energias a ele voltadas, confrontando-se mesmo com as expectativas tidas até ali. O que evidentemente se nota nessa partida é que, do ponto de vista brasileiro, o que era uma derrota provável transforma-se, no seu decorrer, gradualmente, em uma motivação e em uma energia imensurável orientada a uma conquista gloriosa. Os esforços são, a cada lance, recompensados, gerando uma espiral de efervescência que faz sustentar as açóes convergentes e concentradas na direção da vitória, criando assim as circunstâncias criadas pelas próprias habilidades dos jogadores a que essas habilidades prossigam se manifestando. A confiança que cresce a cada novo desafio superado é o esteio dessa energia coletiva que então é produzida e exteriorizada, sustentando a concentração na realização desse grande feito.

Do ponto de vista da equipe norte-americana, o que antes conferia ao confronto uma quase certeza de vitória e uma vantagem indubitável - o fato do país até então ter sido pouquíssimas vezes derrotado em competiçóes internacionais e nunca ter sido derrotado em território nacional -, com as fortes impressōes deixadas pelos fatos no instante vivido, parecia se tornar fonte possível de uma grande decepção, apontando para uma espiral descendente na mobilização de energia. A sensação de choque com uma realidade que denota e provoca a impressão de fraqueza, que se ressalta, em contraste com a suposta superioridade, diante do fato de não ter oferecido resistência à altura das forças percebidas do oponente, redundava em um horizonte ainda mais decepcionante voltado a se mostrar cada vez mais tenebroso e difícil de reverter a cada novo sucesso do adversário (e fracasso próprio), avivando cada vez mais o medo do erro, da possibilidade da derrota que, ao crescer na consciência, mina a confiança no acerto e na vitória, fundamental a um 
espontâneo recrutamento de energia para prosseguir com vigor na disputa.

Cada evento seguiu conformando um sentido subjacente, e ao mesmo tempo expresso nos eventos, que gerava temor, perplexidade e frustração sobre os norte-americanos diante de sua torcida, cometendo sucessivos erros em momentos decisivos, enquanto gerava otimismo, convergência, confirmação de uma possibilidade, até ali mais ou menos remota, entre os brasileiros. As pequenas frustraçôes que se sucederam reduziam cada vez mais a percepção do quão favoritos eram levando consigo as energias disponíveis diante de cada novo erro e de cada novo acerto dos brasileiros. Enxergando cada vez maior incongruência na vitória diante da percepção desequilibrada demais entre o nível do desafio e o das capacidades que os eventos evidenciavam, tornava-se mais difícil ter a sensação dessas energias sendo suficiente e espontaneamente mobilizadas para a disputa em curso, o que concorre para aquele ciclo negativo.

Em uma corrente de acontecimentos, a que todos estão especialmente voltados e atentos, um ou outro evento - nem sempre aqueles que redundam em pontuaçóes, mas eventos que denotam a força (assim como a própria confiança nessa força, cuja demonstração a princípio também denota a própria força) que uma parte parece ter em relação à outra - no modo como se sucedem e se sintetizam, geram maior ou menor impacto, adquirindo um sentido estruturante de todo o encontro. Num momento ou em outro, essa corrente, devido à incidência de repercussão de um ou de uma série de acontecimentos, indica algo que dará um sentido mais preciso ao horizonte comum, à intuição do que se passa, que como vimos passou a confirmar as chances do Brasil perante a incapacidade norte-americana de responder à altura os lances brasileiros.

Esses eventos que denotam força e resistência relativas resultam na sensaçáo de superioridade ou de inferioridade. Considerados justos ou não, resultando em pontuação ou não, eles são dotados pelos jogadores de um significado contextual na sequência em que se inserem, conferindo-se um sentido ou ao menos uma orientação de sentido - de mudança ou permanência - à ordem endógena da relação competitiva, na medida em que, na sucessão que vinham descrevendo, denotam vantagem para um lado e desvantagem para o outro. Encadeados, os eventos ganham um sentido mais claro, com uma percepção mais ou menos nítida acerca do encaminhamento do estado de coisas.

Uma sequência de lances ganha sentidos complementares a cada novo acontecimento, orientando a existência, o sentido da energia a ser engajada e a disposição à ação após cada complementação dos sentidos buscados, na medida em que parecem preceder consolidação ou mudanças. Se eles denotam a contenção do ímpeto adversário, confirmam o sentido anterior. Se não, abatem ainda mais o ânimo de uns, requerendo resistência, e avivam o do outro, fortalecendo a reação.

No limite, no caso da equipe em vantagem, o impacto que certos feitos causam sobre os jogadores em campo, especialmente quando indicam uma proporção significativa da vantagem em relação ao adversário, seja ela expressa no placar ou não, pode também inspirar uma certeza tal da própria superioridade e do controle da disputa a ponto de prejudicar o engajamento das energias no desafio, produzindo efeitos dispersivos e de desmobilizaçáo sobre as açóes individuais já que a força coletiva que as galvaniza se enfraquece tanto quanto o sentido do estar no jogo e do se concentrar esforços para vencer a partida.

Se o presente desafio é percebido como muito aquém das próprias capacidades, reduz-se aquela tensão e incerteza existencial motivante do jogo. E essa tensão depende da percepção de certo equilíbrio entre os competidores e da impressão viva da própria força diante da insegurança quanto à superação possível desse desafio. Então a partida se torna capaz de gerar o impulso que lança os jogadores e os mantêm totalmente imersos na partida, fazendo-os tender a manifestar mais vivamente o elemento coletivo em suas experiências, nesse contexto em que apenas esse elemento é capaz de propiciar tal superação a partir da elevaçáo do nível do nosso jogo e da energia que entấo ele demanda e que, se ainda a temos, tende a obter de nós num esforço coletivo.

A percepção da ausência circunstancial de um oponente com uma força comparável à nossa, contra o qual nos mantenhamos lançados ou motivados a exercer nossa força individual e coletiva - tanto quando se está numa posição de vantagem muito grande no placar, quanto quando se está em uma desvantagem que se percebe insuperável diante da superioridade do adversário - faz com que os jogadores, de certo modo, se encontrem destituídos do impulso existencial originário, central ao desafio, no sentido de fazerem manifestar o que suas equipes possuem de propriamente coletivo, isto é, a força potencial que as constitui na prática viva, contra um oponente digno, a fim de vencê-lo.

Do ponto de vista da constituiçáo comum do horizonte, quanto maior for a distância em relação a uma situação de equilíbrio entre as forças em relação ao 
tempo restante da partida, mais confortável a posição da equipe que está em vantagem, e mais difícil a de quem está em desvantagem, cabendo à primeira manter essa ordem e à segunda, modificá-la. Dependendo da proporção dessa distância e dos limites considerados normais entre os jogadores para sua variação, torna-se mais ou menos esperada a sustentação da vantagem e mais ou menos problemático manter a crença de que é possível alterá-la e a concentração e o engajamento das energias de todos nas disputas.

Quando ainda assim parece possível mudar essas posições na relação, os integrantes da equipe em vantagem mantêm o esforço concentrado no objetivo preciso de conter qualquer ímpeto de reação a fim de manter-se na frente; enquanto os da equipe em desvantagem buscam recrutar as energias que supóem latentes, no sentido de superar o adversário, avivando o sentido de esperança e de potência da equipe.

Como dissemos, no caso de parecer incongruente mudarem as posiçóes, isto é, caso a situação seja percebida como um desafio tâo facilmente superável ou muito difícil, além das próprias forças, ocorre que, num caso, um mínimo de energia é suficiente para vencer, e no outro, nem o máximo das próprias capacidades realizáveis nesse momento podem ser o bastante. $\mathrm{O}$ que, em ambos os casos, pode ser ocasião ou para nos desinteressarmos da partida, restando em nome náo da competitividade, mas da excelência, sair dela de maneira honrosa, ou, especialmente no segundo caso, darmos o máximo de nós e tentar descobrir uma capacidade que não sabíamos ter.

Assim, as situaçóes de jogo podem ser excitantes - quando mantém viva a superação do desafio - ou desalentadoras - quando o desafio começa a se mostrar além das possibilidades de ser superado - ou entediantes - quando ele é percebido como muito aquém das próprias capacidades. Essas propriedades situacionais presentes no horizonte que imediata e espontaneamente a síntese dos eventos apresenta se referem não só à história que essa partida descreve, mas ao que possibilita a forma desse jogo, dentro de limites já naturalizados em sedimentaçóes das experiências práticas anteriores dos jogadores.

Margens consideradas normais de variação na ordem das relaçóes criam ciclos de suspense, tensão, alívio, contentamento, euforia ou frustração e tristeza, peculiares a cada esporte, devido, sobretudo, à própria forma prática em que vantagem ou desvantagem significativa, força ou resistência, se traduzem na formação de horizontes mais abrangentes ou circunscritos, mais definitivos ou circunstanciais, confirmando, intensificando ou arrefecendo nossa vontade e crença de que alcançaremos nosso objetivo em momentos distintos da partida.

Todos os aspectos aqui levantados evidenciam como no jogar conjugam-se e equilibram-se o dominar e o ser dominado, a própria força com a do oponente, enquanto todos são simultânea e continuamente dominados pela prática. Uma vez no jogo, torna-se difícil desvencilhar-se dele. Ele gera um impulso inicial de efeitos inerciais sobre o engajamento de energias submetendo-as à organização da atividade até o fim da partida. No seu curso, a exteriorização do volume dessa energia se distribui de acordo com o formato lógico, por assim dizer, transcendental do jogo, ao funil da forma possível da execução das açóes, que, tomadas individual ou coletivamente, podem ser compreendidas, no modo como seguem sendo sintetizadas, como em uma linha temporal.

A energia que a minha vontade anterior de jogar mobilizou gera um compromisso, um visgo, que me prende à prática e que vai se consumindo na medida em que essas minhas energias, tornadas parte de energias coletivas, vão se esvaindo com os pequenos desafios que se sucedem nas situaçóes da partida. Grandes ou pequenos feitos, insatisfaçóes ou frustraçóes, que podem por sua vez gerar mais ou menos energia diante da gradual constituição de uma sequência favorável ou desfavorável de eventos, se encadeiam em um impulso, anterior e constante, a mais engajamento de energia próprio do competidor.

Uma vez que tenha me engajado verdadeiramente em uma tarefa - isto é, uma vez que tenha assumido sua realidade organizada como a realidade em que efetivamente vivo, em que inteiramente sou, e que dá todo o sentido à minha existência naquele instante - é difícil abandoná-la pela metade, por mais decepcionante que sejam os resultados. $\mathrm{O}$ sentido de seu início, meio e fim é o sentido do meu viver naquele instante e a energia mobilizada por essa disposição mais constante ao engajamento pressupóe esse trajeto.

Sobre essa disposição incide uma força inercial de dentro das disputas, resultante de sua forma, a impulsionar o ser mais para dentro desse mundo e a manter ativa essa energia disponível, uma força que a sucessão dos eventos atualiza. Se sou bruscamente interrompido na continuidade lógica dessa exteriorização, se por alguma razão não posso prosseguir até seu final, sinto-me profundamente frustrado em minhas expectativas naquele instante. Se sou retirado dessa atividade no meio da cadeia da circulação dessas energias, sendo surpreendido, perdendo o sentido de tal envolvimento, experimento um salto traumático em que tudo me falta, e essa energia fica 
sem ter como se esvair, pois ela precisa da forma e da substância compatível e aderente do jogo.

Logo a seguir, quando me recupero da profunda des-in-lusão (a saída da "inlusio" do jogo), finalmente olho para trás, percebo que estava tão absorto que me parece que fora abduzido e me vejo agora consciente de mim e distante da prática, ainda sob os efeitos da decepção de não ter podido continuar a jogar até o fim.

Sair do jogo é difícil. A prática é pegajosa, viscosa, ela gruda, resiste a soltar de nós. E a energia parece ser essa substância grudenta que liga o ser mais próprio ao jogo, ao seu mundo. Eis porque tantos jogadores resistem a sair de campo, contrariados, quando devem ser substituídos, sobretudo em jogos em que o jogador não pode retornar à partida, como no futebol.
A mesma frustração com o fim repentino do jogo ocorre quando se nota que o jogo está sendo roubado. Seu sentido agonístico se dilui, e mesmo com a continuidade da partida, a tensão do desafio parece se dissipar e perde-se em boa medida o interesse. $\mathrm{O}$ visgo da energia se dissolve porque se perde sensivelmente o sentido do provar-se. Há um viés independente de nossas forças em confronto. A energia em convergência, dependente do caráter agonístico do desafio garantido pela regra, então se solta, difusa, sem uma orientação clara, convertendo-se em uma nuvem de des-in-lusão.

De todo modo, sair do jogo é difícil, sobretudo quando as energias de realização não se esvaíram completamente. Há um ciclo energético envolvido na realização de objetivos propostos aos competidores - vencer o jogo. Esse ciclo se remete à unidade temporal de todo desafio.

\section{Notas}

a. Nesse ponto não podemos deixar de fazer uma menção à obra de Norbert ELIAs ${ }^{16-17}$. Para ele, o esporte nasce em um contexto social com características particulares, em termos de determinaçôes sócio-históricas de ordem emocional, que criam as condiçóes para o surgimento do jogo esportivo como o conhecemos. As energias a serem engajadas nesses jogos tornam-se disponíveis em razão de uma nova configuração social específica - formaçáo do estado moderno, aglomeração urbana, o adensamento populacional, diferenciação social, fortalecimento e estreitamento de vínculos de interdependência -, que emerge nos estertores da modernidade, elevando no cotidiano os níveis de tensão e repressão dos impulsos, ocasionando a sociogênese do desporto. Vale enfatizar que nossa perspectiva se volta para a compreensão da geração situada de um circuito de energia e de certa economia dos impulsos no interior dos jogos.

b. Os termos envolvimento e engajamento são aqui utilizados a partir da obra de Goffman. Eles possuem sentidos intercambiáveis de arrebatamento, como o próprio autor menciona ${ }^{18}$. O que afirmo aqui é que a forma e a estrutura da atividade de jogar - próprias do jogo - são fundamentais à manutenção desse envolvimento. Sob sua organização, o jogo se torna capaz de mobilizar atenção e energia dos jogadores, fazendo com que se tornem espontaneamente partes integrantes de uma ocasião. Em relação ao tema especificamente no jogo, veja GoffMAN ${ }^{19}$.

c. O compromisso pessoal com o valor da competitividade e da excelência na prática esportiva cria as condiçóes exteriores ao tempo do jogo que em si impulsionam à busca pelo aperfeiçoamento regular, o que não é exclusivo dessa partida, mas constitui um modo próprio de ser diante do jogo como uma prática, remetendo a posição do jogo na vida do jogador. Não se pode negar que um compromisso individual próprio a cada jogador com o jogo e com seus valores agonísticos projete uma força interior diferenciada entre jogadores à sustentação do envolvimento de energia na disputa. Esse grau de envolvimento também possui um sentido referido ao grupo. Ele deve ser exibido de modo que possa dar conta das expectativas de desempenho entre os colegas de equipe e de torcedores a fim de se esquivar de possíveis cobranças durante a partida ou depois. O compartilhamento daqueles mesmos valores (o acordo não declarado acerca de sua importância e ou a suposição desse compartilhamento já que estão na base do fundamento da associação esportiva) sustenta um compromisso: 1) dos jogadores uns em relação aos outros; e 2), no caso em que elas existem, com a entidade coletiva (clubes ou seleçôes nacionais e as comunidades com eles identificados) do qual fazem parte, como representantes portadores da sua força e tradição. Poderíamos considerar, sobretudo em relação a esse último caso, que se exerce sobre eles uma espécie de força moral difusa da comunidade que a agremiação representa - "imperativa e coercitiva em virtude da qual se impóem a ele (indivíduo), quer ele queira, quer não" ${ }^{20}$ (p.2). Força moral essa que, em relação ao primeiro caso, diria GARFINKEL ${ }^{21}$, se exerce mais concretamente no forte apelo da possibilidade de responsabilização ("accountabillity") (p.173) por parte dos companheiros de equipe ou dos demais circunstantes. A presença de ambas as forças também contribui por se sustentar um certo nível de engajamento de energia. 
d. Essa defesa era muito utilizada no clube que acompanhei - o Fluminense Football Club - em quase todas as categorias. Todos os treinadores compartilhavam fontes táticas, como um site visitado por eles. Nesse site, dentre várias formas de ação, havia essa defesa, a armadilha, ou "trapping"22, que orientava a formação de algumas jogadas.

e. Segundo GoFfman ${ }^{23}$, fabricação consistiria num "esforço intencional de um ou mais indivíduos administrar uma atividade de modo que um ou uma parte dos demais seja induzido a ter uma falsa opinião sobre o que está se passando. Um plano perverso está envolvido, uma trama ou um plano traiçoeiro conduzindo - quando realizado - à falsificação de alguma parte do mundo" (p.83) (minha tradução).

f. Para $\mathrm{S}_{\mathrm{CHUTZ}}{ }^{24}$, partindo de um conhecimento à mão, resultado de nossas experiências pessoais sedimentadas, "toda construção de projeto envolve uma idealização particular, chamada por Husserl de 'I-can-do-it-again,' isto é, a pressuposição de que eu posso agir sob circunstancias tipicamente similares àquela em que eu agi anteriormente para ocasionar um estado de coisas tipicamente similar" (p.20). Aqui trata-se de um sentimento que emerge da situação, mas que pressupõe o sentido difuso de poder fazer que é derivado das experiências já sedimentadas.

g. Como Merleau-Ponty o propóe, isto é, "uma tomada de consciência global de minha postura no mundo intersensorial, [por] uma forma, no sentido da Gestaltpsychologie" (p.145). A compreensão acerca de como essa forma organizaria minha experiência no espaço ao redor, em relação à qual uma espacialidade corporal e a mútua relação entre as partes podem se definir, se revelaria na constituição dos fenômenos práticos em que o ser se encontra envolvido no exercício de habilidades e competências, levando-se em consideração não apenas a espacialidade de posição entre partes do corpo, mas toda uma espacialidade de situação, que, por sua vez, podemos acrescentar, remete à inclusão de objetos nesse espaço envolvidos na tarefa assumida. Para mais detalhes sobre a relação entre fenomenologia do corpo e a Gestaltpsychologie, ver Merleau-Ponty ${ }^{4}$ (p.145-204).

h. Merleau-Ponty ${ }^{4}$ nos diz algo interessante em relação à transposição de gestos do outro ao próprio gesto, numa situação em que se deve imitá-lo, entendida aqui do ponto de vista de uma situaçáo presidida por uma lógica de inter-relação entre os corpos em ação, como naquela em uma competição esportiva. É pelos canais dessa inter-relação que o contágio da energia do movimento se dá. Na imitação normal, a mão esquerda do sujeito adere imediatamente àquela de seu parceiro, a açáo do sujeito adere imediatamente ao seu modelo, o sujeito se projeta ou se irrealiza nele, identifica-se com ele, e a mudança de coordenadas está eminentemente contida nessa operação existencial. Tal fato ocorre porque o sujeito normal possui seu corpo não apenas como sistema de posiçóes atuais, mas também, por isso mesmo, como sistema aberto de uma infinidade de posiçóes equivalentes em outras orientaçóes. O que chamamos de esquema corporal é justamente esse sistema de equivalências, esse invariante imediatamente dado pelo qual as diferentes tarefas motoras são instantaneamente transponíveis. Isso significa que ele não é apenas uma experiência de meu corpo, mas uma experiência de meu corpo no mundo, e que é ele que dá um sentido motor às ordens verbais” (p.196).

\section{Abstract}

\section{Energy and sport experience}

This article is part of an effort to understand what characterizes the condition of player in the practice of collective ball sports such as soccer, basketball, volleyball, among others. From a phenomenological perspective, we sought to understand in particular a constitutive aspect of the experience of playing - energy. How it is mobilized, concentrated and continuously outward actions that are ordered in the way of sports, determining the experience of a unique practical experience? This is our central question to be answered from the phenomenological reduction method, with which we aim to comprehend just how energy plays a fundamental constitutive role to this practical, intersubjective, complete, integrated, fluent and engrossing experience, involving the other, objects, space and time.

\section{KEY WoRDS: Phenomenology; Microsociology; Game; Team sport; Energy.}




\section{Referências}

1. Dewey J. Arte como experiência. In: Os pensadores. São Paulo: Abril; 1974.

2. Schutz A. The phenomenology of the social world. Evanston: Northwestern University; 1967.

3. Husserl E. Ideés directrices pour une phénoménologie. Paris: Gallimard; 1950. Tome premier: introduction générale a la phenoménologie pure.

4. Merleau-Ponty. Fenomenologia da percepção. São Paulo: Martins Fontes; 1999.

5. Schutz A. Fenomenologia e relaçóes sociais. Rio de Janeiro: Zahar; 1979.

6. Bergson H. A evolução criadora. São Paulo: Martins Fontes; 2005.

7. Gurwitsch A. Human encounters in the social world. Pittsburgh: Dunquesne University; 1979.

8. Huizinga J. Homo ludens. São Paulo: Perspectiva; 2005.

9. Heidegger M. Ser e tempo: parte 1. Petrópolis: Vozes; 2005.

10. Garfinkel H. A conception of, and experience with, trust as a condition of stable concerted actions. In: Harvey OJ , organizer. Motivation and social interaction: cognitive determinants. New York: Ronald; 1963. p.187-238.

11. Wittgenstein L. Investigaçôes filosóficas. In: Coleção pensadores. São Paulo: Nova Cultural; 1996.

12. Gurwitsch A. Théorie du champ de la conscience. Desclé De Brouwer; 1957.

13. Csikszentmihalyi M. Flow: the psychology of optimal experience. New York: Harper Perennial; 2008.

14. Cinat E. Mejor jugada de fútbol americano. YouTube; 2010. Esportes, vídeo 26s. [citado 8 fev. 2013] Disponible en: http://www.youtube.com/watch?v=Hu4SpG0orfE.

15. Vidal A. Basquetebol para vencedores. Porto Alegre: Rigel; 1991.

16. Elias N, Dunning E. A busca da excitação. Lisboa: Difel; 1992.

17. Elias N. O processo civilizador: uma história dos costumes. Rio de Janeiro: Zahar; 1994. v.1.

18. Goffman E. Comportamento em lugares públicos: notas sobre a organização social dos ajuntamentos. Petrópolis: Vozes; 2010. p.41-93.

19. Goffman E. Encounters: two studies in the sociology of interaction. Indianapolis: Bobbs-Merrill; 1961. p.17-81.

20. Durkheim E. As regras do método sociológico. São Paulo: Martins Fontes; 1999.

21. Garfinkel H. Ethnomethology's program: working out Durkheim's aphorism. Boston: Rowman \& Littlefield; 2002.

22. Gels J. Basketball defense: basic man-to-man defense. Charlevoix: Coach's Clipboard; 2001. [cited 2008 Jun. 18]. Available from: http://www.coachesclipboard.net/BasicDefense.html.

23. Goffman E. Frame analysis: an essay on the organization of the experience. New York: Harper \& Row; 1974.

24. Schutz A. Collected papers I: the problem of social reality. The Hague: Martinus Nijhoff; 1967.

\begin{tabular}{r|l} 
ENDEREÇO & \\
Eduardo Fernandes Nazareth & \\
Núcleo de Pesquisa Sociofilo & \\
Instituto de Estudos Sociais e Políticos & Recebido para publicação: 10/03/2014 \\
Universidade do Estado do Rio de Janeiro & 1a. revisão: 17/ 04/2015 \\
R. da Matriz, 82 & 2a. revisão: 24/06/2015 \\
22260-100 - Rio de Janeiro - RJ - BRASIL & Aceito: 04/08/2015 \\
e-mail: eduardo.nazareth@gmail.com & \\
&
\end{tabular}

